\title{
Gene Patents, Human Clones, AND Biotechnology Policy: THE Challenges Created by Globalization
}

\author{
TIMOTHY CAULFIELD*
}

In this article, the author explores the implications of globalization on human cloning laws and genetic patent policy, both domestically and internationally. From an international perspective, diverse moral and socio-political positions make cooperation in these areas particularly challenging. As a result, formulating domestic policies becomes challenging as well: should countries try to predict international consensus, or develop strong domestic policies of their own? While there is no clear answer, appreciating the complex issues involved is an essential step in the policy-making process.
Dans cet article, l'auteur explore les implications de la mondialisation sur les lois régissant le clonage humain et la politique des brevets en génétique, autant à l'échelle nationale qu'internationale. Du point de vue international, les diverses positions morales et sociopolitiques rendent la coopération dans ces secteurs particulièrement intéressante. Par conséquent, il est également difficile d'élaborer des politiques intérieures; les pays devraient-ils essayer de prédire un consensus international ou plutôt développer seuls de solides politiques intérieures? Bien qu'il n'existe pas de réponse claire, il est essentiel de comprendre les questions complexes pertinentes pour pouvoir élaborer des politiques.

\section{TABLE OF CONTENTS}

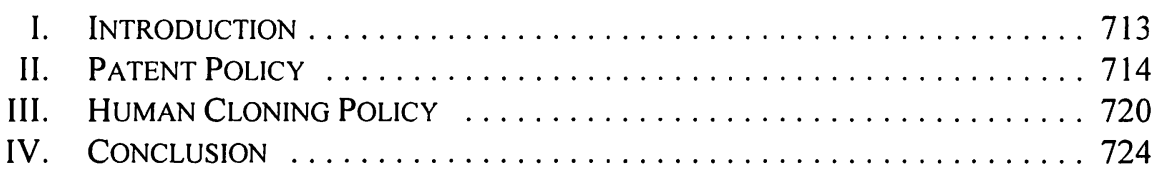

\section{INTRODUCTION}

In the context of biotechnology, globalization adds further complexity to policy-making in an area that is already clouded by moral ambiguity, regulatory uncertainty, and rapid scientific advance. Globalization forces, such as the rapid dissemination of scientific knowledge and the international nature of the biotechnology industry, suggest that the world community should, as much as possible, coordinate regulatory policy. Without such coordination, there is likely to be a degree of corporate forum-shopping and we will be unable to respond rapidly to emerging intellectual property issues or broader ethical, social, and legal concerns.

That being said, for many of the emerging policy issues international cooperation seems largely unattainable, at least in the short term. More importantly, cooperation may be premature. There remains a high degree of uncertainty in the international community about even basic issues, such as the application of concepts of human dignity in the context of

Canada Research Chair in Health Law and Policy, Associate Professor, Faculty of Law and Faculty of Medicine and Dentistry, Research Director, Health Law Institute, University of Alberta. I would like to thank Cathy Jo Kickham, Lori Sheremeta, Tim Outerbridge, and Nina Hawkins for valuable assistance and Genome Prairie, the Stem Cell Network, and the Alberta Heritage Foundation for Medical Research for their continued support. I would also like to thank the reviewers for their thoughtful comments. 
reproductive cloning, the moral and legal status of the embryo, and the value, role, and impact of gene patents. Of course, such issues have also made it difficult to develop domestic laws. At the international level, however, the differing cultural and socio-political positions magnify the policy-making challenge.

This article examines a few of the implications of globalization on the development of domestic and international biotechnology policy in two areas: human cloning laws and genetic patent policy. Both topics have generated calls for international cooperation and, at the same time, have also highlighted the challenges associated with that goal. In addition, they demonstrate that while there are reasons to seek international consensus on these topics, there are also regional needs that will not necessarily be satisfied by the development of a homogenous regulatory approach.

This article is meant to give the reader a flavour of the issues created by globalization pressures and is not a comprehensive analysis of this complex area. In fact, for those scholars close to the issues associated with globalization, many of my observations may seem obvious. However, in the context of Canadian biotechnology policy, the role of globalization is just starting to permeate the national debate. This will change. As governments throughout the world struggle to develop policies to meet the unique social concerns created by biotechnology, appreciating the relevance of globalization, one of this era's defining phenomena, seems essential.

\section{Patent Policy}

One truism of globalization is that individual countries are increasingly viewed as merely players in a large, inter-connected, international economy. ${ }^{\prime}$ As such, policy-makers within countries motivated by economic development must now ask, "how will this policy decision be perceived by international investors and markets"? In the fragile, knowledge-based sector of biotechnology, considerations of globalization seem particularly important. As suggested by Lester Thurow: "The knowledge-based economy is fundamentally transforming the role of the nation-state. Instead of being a controller of economic events within its borders, the nation-state is increasingly having to become a platform builder to attract global economic activity to locate within its borders."2 An examination of the field of human gene patents illustrates the challenges created by the interplay between the forces of globalization and national policy. The economic reality of global competition adds a layer of complexity that has the potential to frustrate the most worthy suggestions for patent reform and to intensify the already apparent conflict between the national health care and innovation agendas. ${ }^{3}$

1 See generally United Nations, United Nations Environment Programme (UNEP), "Integrating Environment and Development: 1972-2002" in GEO: Global Environmental Outlook 3, online: United Nations Environment Programme <www.unep.org/geo/geo3/english/pdfs/Chapterl.pdf> at 24.

Lester Thurow, "Globalization: The Product of a Knowledge Based Economy" (2000) 570 Ann. Am. Acad. Polit. Soc. Sci. 19 at 21.

1 address the conflict in more detail in Timothy Caulfield, "Sustainability and the Balancing of the Health Care and Innovation Agenda: The Commercialization of Genetic Research" (2003) 66 Sask. L. Rev. 629-45; see also E. Richard Gold, "Biotechnology Patents: Strategies for Meeting Economic and Ethical Concerns” (2002) 30 Nat. Genet. 359. 
Though human gene patents have long been a source of social controversy, ${ }^{4}$ there has been little doubt about the patentability of human genes - at least from the perspective of patent offices throughout the world. Following the trend set by the influential 1980 U.S. Supreme Court case of Diamond $v$. Chakrabarty, ${ }^{5}$ if an inventor can isolate, purify, and make useful a naturally occurring substance, even human DNA, it has the potential to be deemed patentable. $^{6}$

The biotechnology industry is closely tied to patent policy. Few other industries rely on patent protection as much as this sector. ${ }^{7}$ It is not surprising then that a huge number of DNA patents have already been applied for or granted. ${ }^{8}$ Because potential biotechnology products can take years to bring to market, investors believe that they need strong intellectual property (IP) protection in order to provide a small sense of long term security. Indeed, when a rough map of the human genome was completed in 2000, President Clinton and Prime Minister Blair made a joint announcement suggesting that the "gene map belongs to all." The statement was not meant to implicate patent policy. Nevertheless, the fear that the two leaders would seek to diminish intellectual property protection sent stocks in biotechnology companies tumbling. ${ }^{10}$

Although gene patents have long been perceived as a necessary component of the commercialization process, they have also been associated with many ethical, legal, and social issues. The concerns are varied, including issues about commodification, human dignity, and "biopiracy." "However, the intensifying concerns about the impact of human gene patents on future health research and access to useful technologies seem to have

4 It is beyond the scope of this article to discuss all of the social controversies that have been associated with human gene patenting. See generally Lori B. Andrews, "The Gene Patent Dilemma: Balancing Commercial Incentives with Health Needs" (2002) 2 Houston J. Health L. \& Pol. 65; and Timothy Caulfield, Richard Gold \& Mildred Cho, "Patenting Human Genetic Material: Refocusing the Debate" (2000) 1 Nat. Rev. Genet. 227.

$5 \quad$ See generally Lori B. Andrews and Dorothy Nelkins, Body Bazaar: The Market for Human Tissue in the Biotechnology Age (New York: Crown Publishers, 2001).

" See V. Walsh, "Biotechnology and the U.K. 2000-05: Globalization and Innovation" (2002) 21 New Genetics and Society 149 at 159 where it is noted: "[t]here has been an ever increasing expansion of intellectual property protections, especially since the Second World War, and, more recently, rapid change in IPRs [intellectual property rights] in relation to biotechnology and what the public expects." Even products of nature are patentable "even though the novelty of human ingenuity involved might simply be purification or isolation from a plant or animal raw material" (ibid. at 160 ). Robert Mullan Cook-Deegan \& S.J. McCormack, "Patents, Secrecy and DNA"(2001) 293 Science 217; and Joseph Straus, "Bargaining Around the TRIPS Agreement: The Case for Ongoing Public-Private Initiatives to Facilitate Worldwide Intellectual Property Transactions" (1998) 9 Duke J. Comp. \& Int'I L. 91 .

\& See Cook-Deegan \& McCormack, ibid. who estimate that as of the year 2000, over 25,000 DNA-based patents have been issued in the U.S. alone; see also, Sandy Thomas, Michael Hopkins \& Max Brady, "Shares in the Human Genome - The Future of patenting DNA" (2002) 20 Nat. Biotechnol. 1185 at 1185, who claims that "between 1996 and 1999, 6786 patents were filed" in the U.S., Europe and Japan.

9 Brad Evenson "Gene Map Belongs to All" (15 March 2000) National Post Al at Al.

11 Robert Schehr \& Jeff Fox, "Human Genome Bombshell," (2000) 18 Nat. Biotechnol. 365.

1 See e.g. Timothy Caulfield, E. Richard Gold \& Mildred Cho, "Patenting Human Genetic Material: Refocusing the Debate" (2000) I Nat. Rev. Genet. 227; D.B. Resnick, "DNA Patents and Human Dignity" (2001) 29 J.L. Med. \& Ethics 152; and L. Sarma, "Biopiracy: Twentieth Century Imperialism in the Form of International Agreements" (1999) 13 Temple Int'l \& Comp. L.J. 107 
provided impetus for the most recent policy recommendations calling for specific patent reform. ${ }^{12}$ Given the importance and profile of health care to most national and regional political agendas, ${ }^{13}$ it is hardly surprising that a perceived adverse impact on access, cost, and sustainability would generate a desire to re-examine the role and value of patents. ${ }^{14}$ This is particularly true in jurisdictions with public health care systems, where there is growing concern that gene patents may have an impact on the cost of the overall system.

In the past few years many policy-making entities have provided suggestions on how to mediate the adverse effects of patents on the health care and research agendas. For example, in late 2002, the U.K. Nuffield Council on Bioethics recommended, inter alia, that patenting criteria (utility, novelty, and non-obviousness) be more stringently applied, that patents over research tools be discouraged, and that "compulsory licensing may be required to ensure reasonable licencing terms." ${ }^{.15}$ In Canada, there are also examples of calls for patent reform. The Ontario government's Report to the Premiers, adopted by all premiers at a Premiers' Conference in Vancouver on 24-25 January 2002, recommends a clarification of several patent criteria. Specifically, the report discusses human genes, the exclusion of broad-based genetic patents covering multiple uses, a clarification of the experimental and noncommercial exceptions, and an expansion of the methods of medical treatment exclusion. ${ }^{16}$ More broadly, the Ontario Report to the Premiers suggests that: "The goal of any patent reforms should be to uphold the beneficial aspects of patent law (for example, encouraging research, invention, and innovation) while ensuring a better balance between public and private interests with appropriate transparency and rigour." 17

12 In Canada, this patent dilemma was moved to the front of the policy making agenda by Myriad Genetics' decision to send "cease and desist" letters to provincial labs testing for the BRCA1/2 mutations. Myriad Genetics, a U.S. company, owns the patent on these genes and therefore has legal control over all testing. The company insisted that all testing be done through their Utah-based laboratory. The Myriad test is quite expensive as compared to the testing process already being done in Canada (Myriad charges more than $\$ 3,800$ CND per test); see Robert Benzie, "Ontario to defy U.S. patents on cancer genes: Province will pay for $\$ 800$ test, not $\$ 3,850$ version by Myriad Genetic Laboratories Inc. 'Share the benefits'" National Post (20 September 2001) A15; see also, Richard Gold, Timothy Caulfield \& Peter Ray, "Gene Patents and the Standard of Care" (2002) 167 Can. Med. Assoc. J. 256; and Lucinda Hahn, "Owning a Piece of Jonathan" (May 2003) Chicago 83, for a discussion of a similar controversy surrounding the patenting and commercialization of the Canavan gene.

See generally Commission on the Future of Health Care in Canada, Building on Values: The Future of Health Care in Canada (Ottawa, Government of Canada, 2002) online: Health Canada <www.hcsc.gc.ca/english/pdf/case/romanow_e.pdf $>$.

As noted by Lori $\mathrm{B}$. Andrews, "Gene patents are undergoing increasing scrutiny because they are pivotal to the future of health care, and patent decisions around the globe have been most challenged and changed when health is at issues" (supra note 4 at 67).

15 Nuffield Council on Bioethics, The Ethics of Patenting DNA (London: Nuffield Council on Bioethics, 2002) at xi-xii, online: Nuffield Council on Bioethics <www.nuffieldbioethics.org/ patentingdna/index.asp $>$ [Ethics of Patenting]; see also Royal Society (U.K.), Keeping Science Open: The Effects of Intellectual Property Policy on the Conduct of Science (London: The Royal Society. 2003) online: The Royal Society <www.royalsoc. ac.uk> at 3.19: "We recommend that governments further facilitate compulsory licensing and application of competition law in situations where single or multiple patents do, on balance, unreasonably affect use and development of inventions."

Ontario, Report to Premiers, Genetics, Testing and Gene Patenting: Charting New Territory in Healthcare (Ottawa: Government of Ontario, 2002) online: Ministry of Health and Long-Term Care $<$ www.health.gov.on.ca/english/public/pub/ministry_reports/geneticsrep02/report_e.pdf $>$ [Ontario Report].

$17 \quad$ Ibid. at 15 
Globalization, however, will make implementing reform, even moderate reform, challenging for several reasons. First, existing international trade agreements, which are part of the globalization phenomenon, have the potential to create technical barriers for those seeking to alter established patent rules. For example, the Trade-Related Intellectual Property Rights (TRIPS) agreement of the World Trade Organization came into effect in 1995 and currently involves 146 nations including Canada. It was designed to harmonize and promote strong patent protection. ${ }^{18}$ This agreement was built on the premise that strong intellectual property protection was needed to promote innovation and economic growth and may leave little room for unilateral patent reform. As such, it is unclear whether the recommendations made by entities like the Nuffield Council on Bioethics and the Ontario government would survive a challenge under TRIPS. ${ }^{19}$ At a minimum, existing international treaties add an element of uncertainty to the policy-making process.

Second, because intellectual property has become so closely tied to the broader political goal of economic development, ${ }^{20}$ any reform that has the potential to adversely impact the economic value of patents will meet a degree of resistance from both industry and those within government who are motivated by economic growth. Indeed, intellectual property protection is increasingly viewed as the economic foundation of the knowledge-based economy. ${ }^{21}$ Juan Enriquez has gone so far as to suggest that a country or region's economic worth can be measured by the patents it produces. As he states: "Patents are a good window (although not the only window) on who might triumph and who might lose over the course of the next two decades." ${ }^{22}$ In biotechnology, patents are believed, rightly or not, ${ }^{23}$ to be an

TRIPS was, to some degree, a direct result of the U.S. trade policy and the U.S. government "taking a very hard line against global piracy and pressuring foreign governments with weak patent laws to strengthen them" (Hon. Bruce Lehman, "Making the World Safe for Biotech Patents" (Boston: International Intellectual Property Institute, 26 June 2002) at 2).

In Timothy Caulfield et al., "Genetic Technologies, Health Care Policy and the Patent Bargain" (2002) $63 \mathrm{Clin}$. Genet. 15 , we argue that it is theoretically possible to implement a mandatory licencing scheme under TRIPS; see also Andrews, supra note 4 at 76, who notes that: "Article 8 of TRIPS allows governments to take public health concerns into consideration with their national intellectual property laws." However, given the aggressive position of U.S. on intellectual property issues, such an approach could face a challenge; see also, Elisa M. Buctuanon, "Globalization of Biotechnology" (2001) 20 New Genetics and Society 25 at 34: "the U.S. influence over IPR [intellectual property rights] extends to the Trade Related Aspects of Intellectual Property (TRIPS) issues in the WTO because of the enormous stake of American firms on biotechnology products sold in the world market." See generally, Keith Aoki, "Sovereignty and the Globalization of Intellectual Property" (1998) 6 Int. J. Global Leg. Stud. 11.

21 See Thurow, supra note 2 at 28: "The ownership of intellectual property rights - the ultimate source of wealth in a knowledge based economy - is one of the most important and most contentious unresolved issues."

22 As the Future Catches You (New York: Crown Business, 2001) at 138. Later, Enriquez argues: "What matters in a modern economy is knowledge. It is what you live off. It is what powers growth. And from patents in the last twenty years it is not hard to predict who gets rich and who gets poor" (ibid. at 142). It is important to note that though this is the perception in industry, there remains little evidence to support the claim. As noted by Richard Gold, et al: "Despite the assumption within intellectual property systems that they are necessary to encourage research and development, there is only a modest body of empirical evidence to support this in the biotechnology industry" ("Needed: Models of Biotechnology Intellectual Property" (2002) 20 Trends in Biotechnol. 327 at 327); see also, Frederic Scherer, "The Economics of Human Gene Patents" (2002) 77 Acad. Med. 1348 at 1363: "Offering patent rights cannot motivate what has already been done, it can only confer windfalls for past investments made without the clear expectation that patent rights could be secured." 
absolutely essential element of the innovation and commercialization process. ${ }^{24}$ Janet $^{2}$ Lambert, President of BIOTECanada, the national association of biotechnology researchers and practitioners, summarizes the industry position regarding biotechnology patents:

Intellectual property is often the most valued asset for biotechnology researchers and companies, particularly those who have yet to commercialize a product. The majority of Canadian biotechnology companies do not have revenues, are spending their capital on research, are small to medium sized businesses and are faced with increased international competition for funding and human resource skills. It is by ensuring Canada is internationally competitive in our protection of IP, that our voice as a society is heard in the vital social and ethical debates needed to define the boundaries of biotechnology. ${ }^{25}$

Finally, it is hard to overestimate the potential influence of U.S. policy in this context. A large proportion of the biotechnology industry is centred in the U.S., including most of the venture capital, much of the scientific activity, and a large percentage of the consumer market. ${ }^{26}$ This fact is reflected in the country's strong pro-patent approach to biotechnology. As noted by Elisa Buctuanon: "[b]eing the world's major source of biotechnologies, it is but natural for the U.S. system to secure the best protection of innovations generated." 27 Not surprisingly, most human gene patents have been filed in the U.S. Sandy Thomas, et al., found that of the human gene patents filed between 1996 and 1999, " $62 \%$ were filed by organizations in the United States, $20 \%$ in the European Union, and 10\% in Japan." 28 Likewise, a study by the Organization for Economic Co-operation and Development(OECD)

See generally Joseph Straus, supra note 7; and Buctuanon, supra note 19 at 34, where the author reports on a survey of biotechnology companies:

"[T]he Intellectual Property Rights (IPR) regime emerged as the fourth crucial factor identified by the companies. This is because the risks and costs inherent in the development of biotechnology products are so high that the ability of a country to secure property interests (products, processes and know-how) becomes an incentive that will encourage firms to invest more in R\&D."

Canada NewsWire, "BIOTECanada responds to Supreme Court Decision on Harvard Mouse Case" (5 December 2002) online: Canada News Wire <www.newswire.ca/en/releases/archive/December 2002/05/c0202.html>. I offer this quote merely to highlight the perception of the biotechnology industry. The reaction of the biotechnology community to Harvard College v. Canada (Commissioner of Patents) (2002), 21 C.P.R. (4th) 577 [Harvard Mouse], which held that higher life forms are not patentable, stands as a good example of how industry and policy-makers may respond to patent reform. Even though patents on higher life forms arguably play a very small role in the broader biotech industry, the decision elicited a strong response; see Daniel Gervais, "Eeek! The Mouse Confounds the House!" The Ottawa Citizen (14 December 2003) B7 at B7: "While the teclnical impact of the decision will likely be minor, the negative effect on future biotechnology could be huge"; see also Canada NewsWire, ibid., where Janet Lambert suggests: "[t]oday's decision destroys our Canadian infrastructure of knowledge and innovation, creates an even greater brain drain, and we will lose our place at the world table in influencing how and where society accepts this technology"; see also Carolyn Abraham "Mouse Ruling May Stall Research" The Globe and Mail (6 December 2002) AI.

As noted by Elisa M. Buctuanon, "Globalization of Biotechnology" (2001) 20 New Genetics and Society 25 at 26 : "it appears that although the flow of biotechnology across national borders has grown, increasingly in recent years, there is a tendency for this to agglomerate in developed countries, particularly the U.S., where the socio-economic and politico-institutional environment facilitates their development and commercial exploitation." Later, the author notes that "[a] close examination on the direction of firms in the forming strategic R\&D partnerships reveals that they are headed toward the U.S. for insourcing biotechnologies" (ibid. at 29). 
found that the U.S. has by far the most biotechnology patents generally. ${ }^{29}$ Of course, this reality has particular relevance to Canada, as any lessening of our IP protection will stand in sharp contrast to the policies promoted by our largest trading partner.

More than anything, the forces of globalization intensify the policy tension between some social goals, such as the desire to create a sustainable health care system, and the commercialization and innovation agenda. If, in fact, gene patents have an adverse impact on access to useful technologies and inappropriately drive up the cost of health care generally, ${ }^{30}$ governments must seek ways in which to strike an appropriate balance. Indeed, as intellectual property becomes an increasingly important part of the global economy, patents will concomitantly have a more significant impact on other social structures, such as health care systems and research institutions. Because social systems and needs can vary greatly between nations, a degree of flexibility thus seems appropriate. ${ }^{31}$ Unfortunately, existing globalization forces, particularly those emanating from the U.S., allow for little policy experimentation and largely push in one direction - toward strong and uniform intellectual property laws. As Lester Thurow points out: "A global system will have to allow for a diversity of economic positions and beliefs, but how is that system to come into existence?"32

Given this state of affairs, countries with modest economic influence have a number of choices. First, they can move forward with patent reform and accept the probable though perhaps short-term backlash from the global economy. ${ }^{33}$ This may also include legal challenges under existing international agreements like TRIPS. The implementation of some form of compulsory licencing for genetic innovations, for example, may not be willingly accepted by the international community. Second, they can seek to make minor revisions that

Biotechnology Statistics in OECD Member Countries (13 September 2001) online: OECD $<$ www.olis.oecd.org $>$.

A detailed discussion of the evidence supporting these concerns is beyond the scope of this article. See generally Milred Cho et al., "Effects of Patents and Licences on the Provision of Clinical Genetic Testing Services" (2003) 5 Journal of Molecular Diagnostics 3; and Caulfield, supra note 3.

3 Of course, existing intellectual property rights create far greater challenges for the developing world Though a discussion of this issue is beyond the scope of this article, it is worth noting that a growing "genomics divide" is emerging. "[H]ealth research is disproportionately directed to the developed world, leading to the so-called 10/90 gap - 10 percent of the world's population accounts for 90 percent of research expenditure dedicated to health." Elizabeth Dowdeswell, Abdallah Daar \& Peter Singer, "Bridging the Genomics Divide" (2003) 9 Global Governance: A Review of Multilateralism and International Organizations 1 at 2-3; see also Andrew Davidge \& Marc Saner, Bridging Troubled Waters: Canada's Role in Connecting Biotechnology to Global Human Needs (Ottawa: Institute on Governance, 2003) online: Institute on Governance <www.iog.ca/s\&tgov/june3briefing.pdf $>$ at 6 : "Signing on to TRIPS and thereby adopting a Western-style intellectual property regime greatly increases the cost of new technologies. TRIPS consolidates the position of technological leaders but does little spread the wealth."

$32 \quad$ Supra note 2 at 29

33 One can only guess what the economic fallout out of drastic patent reform would be. Many suggested that the Harvard Mouse decision (supra note 25) would have a dramatic impact. To my knowledge, this has yet to materialize. However, a reform that would have more obvious ramifications to the commercialization process, such as compulsory licencing, may elicit a more substantial response from industry. Nevertheless, policy makers may feel that alleviating the potential adverse effects of genc patents on the cost of the health care system would offset the economic loss created by patent reform and therefore, in the aggregate, patent reform is justified. Clearly, more empirical evidence is needed to inform this type of policy-making. 
work within the existing patent rules and do little to alter the commercializability of useful technologies. The suggestion to apply existing patent criteria more stringently, particularly that of utility, would be an example of this approach. ${ }^{34}$ Finally, Canada could work with the world community with a goal of developing an international patent policy that is more sensitive to the needs of public health care goals. Unfortunately, as highlighted above, the existing globalization pressures makes this latter strategy the most challenging.

\section{Human Cloning Policy}

With some technologies, globalization also creates an apparent need for a high degree of international cooperation. More than ever before, technologies and information can easily move between countries. As such, if the regulatory goal is to contain or to ensure the safe application of a given genetic technology, some level of agreement between nations will be needed to control both the development and the flow of such technologies. As noted by Allyn Taylor, the genetic revolution is "inherently international, necessitating collaborative multinational cooperation to promote global public health and to protect human rights while advancing scientific research and discovery." ${ }^{35}$

The emerging attempts to regulate cloning and stem cell technologies at the level of both national and international policy stand as good examples of the challenges created by globalization in the context of morally contentious areas of research. For example, if the world community agrees on a need to address the concerns related to the ethics of human reproductive cloning, ${ }^{36}$ international cooperation seems necessary. Without such cooperation, those who wish to proceed with the technology will merely need to locate in a jurisdiction without specific cloning laws. ${ }^{37}$ This kind of forum-shopping has the potential to undermine the regulatory goals of protecting human safety and dignity. ${ }^{38}$

See e.g. Ethics on Patenting, supra note 15; see also the United States Patent and Trademark Office (USPTO) 2001 utility guidelines (Federal Registry, Vol. 66, No. 4, January 5, 2001); and, for a discussion of other possible patent reforms, see Lori Sheremeta \& Richard Gold, "Creating a Patent Clearinghouse in Canada: A Solution to Problems of Equity and Access?" [poster] GE'LS Winter Symposium (Montreal: Genome Canada, 6-8 February 2003).

35 "Globalization and Biotechnology: UNESCO and an International Strategy to Advance Human Rights and Public Health" (1999) 25 Am. J.L. \& Med. 479 at 480.

36. A detailed critique of the concerns associated with human reproductive cloning is beyond the scope of this article. For a recent interesting article on point see Judith Daar, "The Prospects of Human Cloning: Improving Nature of Dooming the Species" (2003) 33 Seton Hall L. Rev. 511; see also G. Annas, L.B. Andrews \& R. Isasi, "Protecting the Endangered Human: Toward and International Treaty Prohibiting Cloning and Inheritable Alterations" (2002) 28 Am. J.L. \& Med. 151; and S. Pattinson, "Reproductive Cloning: Can Cloning Harm the Clone?" (2002) 10 Med. L. Rev. 295-307.

It has also been suggested that an international ban on human cloning could never be truly effective because it would merely drive the research underground and to jurisdictions with little oversight of human research. Indeed, some commentators believe that a ban will "only encourage development of irresponsible and ill conceived research agenda" (Daar, supra note 36 at 571). As such, Daar advocates the development of a regulatory scheme that allows the technology to be developed and applied in a responsible manner (ibid.).

Concern for human safety is largely viewed as a logical justification for the regulation of human reproductive cloning. See e.g. National Bioethics Advisory Commission, Cloning Human Beings (Rockville, Maryland, 1997) online: Georgetown University <www.georgetown.edu/research/nrcbl/ nbac/pubs/cloningl/cloning.pdf $>$. See also J. Giles \& J. Knight, "Dolly's death leaves researchers woolly on clone ageing issue" (2003) 421 Nature 776. At the current time, however, there remains a great deal of disagreement about the role of human dignity in this context. Nevertheless, the protection 
There are numerous obstacles to making policies that will have relevance to the world community. For example, the moral ambiguity that permeates the national discourse about the regulation of cloning technology is amplified on the international stage. Cultural, religious, and political variations between nations make a consensus, at least on some topics, seem all but impossible. ${ }^{39}$ There is an emerging agreement that reproductive cloning should not be allowed. ${ }^{40}$ However, other technologies and procedures, such as "research cloning," are much more divisive. ${ }^{41}$ Even among relatively culturally similar Western nations drastically different regulatory approaches are emerging. For example, within the European Union, consensus has been difficult to obtain. Belgium and the U.K. allow the creation of embryos for research purposes. Finland, Greece, the Netherlands, and Sweden allow the procurement of stem cells from spare embryos. Austria, Denmark, Ireland, and Spain all prohibit the creation of stem cell lines from embryos. ${ }^{42}$ In the U.S., states vary greatly in their approach to the regulation of research cloning. California and New Jersey have decided to explicitly allow cloning for research purposes while other states have already passed laws banning all forms of somatic cell nuclear transfer. ${ }^{43}$ And at the level of the U.S. federal government, the President's Council on Bioethics' Report recently noted that a "moral

of human dignity is an often-used justification for cloning laws: see generally $D$. Beyleveld \& $R$. Brownsword, "Human Dignity, Human Rights, and Human Genetics" (1998) 61 Mod. L. Rev. 661; S Malby, "Human Dignity and Human Reproductive Cloning" (2002) 6 Health Hum. Rights 103-35; T George Wright, "Second Thoughts: How Human Cloning Can Promote Human Dignity" (2000) 35 Val. U.L. Rev. 1-35; and Timothy Caulfield, "Human Cloning Laws, Human Dignity and the Poverty of the Policy Making Dialogue," (2003) 4 BMC Medical Ethics 3.

Of course, in the context of embryonic stem cell research and research cloning, a great deal of the variation in approaches can be traced to views on the moral and legal status of the embryo. For example, among the major religions we see vastly different positions. See J. Evans, "Religion and Human Cloning: An Exploratory Analysis of the First Available Opinion Data" (2002) 41 J. Sci. Stud. of Relig. 747-58; and J. Evans, "Cloning Adam's Rib: A Primer on Religious Responses to Cloning" (Washington D.C.: Pew Forum on Religion and Public Life, 2002) online: Pew Forum on Religion and Public Life <www.pewtrusts.com/pdf/rel_pew_forum_adams_rib.pdf $>$.

For example, a 2002 Gallup poll found that 90 percent of Americans disapprove of cloning that is designed specifically to result in the birth of a human being. See Lydia Saad "“Cloning' Humans is a Turn Off to Most Americans," Gallup News Service (16 May 2002) online: Center for Genetics and Society < www.genetics-and-society.org/analysis/opinion/detailed.html >.

41 "Research cloning," also referred to as non-reproductive human cloning and therapeutic cloning, involves the use of somatic cell nuclear transfer for the purpose of cloning an "embryo" for research purposes. It is hoped that this technique could be used to create cell lines for research purposes or, even, tissue for transplantation. See Abdallah Daar \& Lori Sheremeta, "The Science of Stem Cells: Some Implications for Law and Policy" (2002) 11 Health L. Rev. 5.

42 See Anna Meldolesi, "EU Stalls on Funding ES Cell Research" (2003) 21 Nat. Biotechnol. 588; and Peter Gruss, "Human ES Cells in Europe" (2003) 301 Science 1017 at 1017: "There is a bewildering array of positions on human ES cells in Europe." To add more confusion to the European scene, Germany prohibits embryonic stem cell research but allows the importation of human embryonic stem cell lines; see also D. Wertz, M. Régnier \& B.M. Knoppers, "Stem Cells in a Pluralistic Society: Consequences of Proposed Canadian Legislation" GenEdit (Montreal: University of Montreal, 2003) online: University of Montreal <www.humgen.umontreal.ca/en/GenEdit.cfm $>$. I discuss the various approach to the regulation of "research cloning" in Timothy Caulfield, "The Regulation of Embryonic Stem Cell Research: A Few Observations on the International Scene" Health L.J. [forthcoming in 2003]. See C. Holden, "California Flashes A Green Light" (2002) 297 Science 2185; California Advisory Committee on Human Cloning, Report of the California Advisory Committee on Human Cloning online: SFGate.com <www.sfgate.com/chronicle/cloningreport>. 
consensus" does not exist on the topic of cloning. ${ }^{44}$ In Canada, there is strong public support for the research and the government seems likely to take a middle ground approach, allowing and funding embryonic stem cell research, but prohibiting the creation of embryos for research purposes. ${ }^{45}$

This diversity of national and regional regulatory approaches makes the development of a single international position seem unlikely. As suggested by Jessica Monachello: "Although most nations agree and have passed laws banning cloning to produce children, a world wide consensus on the topic of cloning for biomedical research seems virtually impossible." 46

In addition, while many of the Western nations with well-developed research infrastructures have cloning and stem cell policies, most countries in the world have no relevant laws or policies. ${ }^{47}$ For many countries, the creation of biotechnology policy is far from a national priority. As such, in a significant portion of the world, particularly in developing nations, there is little to stop those wishing to proceed with the development of controversial technologies. For an international approach to be effective, the domestic laws in all relevant jurisdictions will need to be developed to at least some minimum level.

The difficulty in developing international policy in this area is well illustrated by the failed attempts of the United Nations (U.N.) to produce a treaty on reproductive cloning. The most recent draft that would have focused on reproductive cloning was blocked by countries that wanted to see a more comprehensive ban of all forms of cloning technology. The U.N. debate is scheduled to continue in the Fall of $2003 .^{48}$

This regulatory gridlock creates an interesting policy dilemma. Globalization increases the need for an international approach to policy-making in this context. At the same time, an international approach to the regulation of all cloning technology requires us to subvert the diversity of cultural positions on central moral issues, most notably the moral and legal status of the embryo. All can agree that reproductive cloning is currently an unsafe technology and,

United States of America, The President's Council on Bioethics, Human Cloning and Human Dignity: An Ethical Inquiry (Washington, D.C.: U.S. Government Printing Office, 2002), online: The President's Council on Bioethics <www.bioethics.gov/cloningreport/fullreport_print.httm>.

See Bill C-13, An Act Respecting Assisted Human Reproduction, 2nd Sess., 37th Parl., 2002. The passage of this bill has been delayed yet again, until at least the fall of 2003. In part, this delay is due to the lack of consensus in Parliament surrounding research involving embryos: see Norma Greenaway, "Bill's Delay is Final Straw for Stem-Cell Researchers" National Post (16 June 2003) Al; for data regarding the views of Canadians, see Pollara \& Earnscliffe, Public Opinion Research Into Biotechnology: Sixth Wave (Ottawa, Biotechnology Assistant Deputy Minister Coordinating Committee (BACC), Government of Canada, June 2002) at 12: "Awareness and recall of stem cell research hovers over 60 percent with the vast majority of Canadians being at least somewhat supportive of the research. The number of people adamantly opposed has dropped five points to 13 percent of the population. Further, a vast majority of Canadians believe it is very or somewhat acceptable for the Government of Canada to be involved in supporting this type of research." Jessica Monachello, "The Cloning for Biomedical Research Debate: Do the Promises of Biomedical Advances Outweigh the Ethical Concerns?" (2003) 10 Tulsa J. Comp. \& Int'l L. 591 at 14.

47 See Andrea Bonnicksen, Crafting A Cloning Policy: From Dolly to Stem Cells (Washington, D.C.: Georgetown University Press, 2002).

48 See "Cloning Conundrums," Editorial (2002) 8 Nat. Med. 1331 at 1331 ["Conundrums"], where it is noted that a U.N. ban on research cloning would "set a precedent for global restrictions on basic research." 
as such, policy-makers can easily justify a ban on the basis of that concern alone - even if other justifications, like the impact of reproductive cloning on human dignity, remain hotly contested. ${ }^{49}$ However, the concerns associated with other uses of cloning technology, such as its use for research purposes, are based almost entirely on ethical principles that may be closely tied to a given region's specific history or culture. ${ }^{50}$ We could hope for a degree of compromise and the finding of a middle ground. International agreements are, after all, often built around compromise. But in the areas of stem cell research and human cloning, the values at play are either not amenable to compromise (as with some views on the moral status of the fetus) or they remain disputed or underdeveloped (as with the application of the notion of human dignity). This is hardly the atmosphere to build thoughtful and lasting international agreements.

As such, unless we are willing to accept that the process of developing an international agreement may itself become a globalization force that homogenizes and simplifies complex and hotly debated ethical positions, we must allow room for national variation and continued public debate. Admittedly, this will mean that in jurisdictions that wish to immediately ban all forms of cloning, policy makers must accept the reality that a degree of forum-shopping may inevitably soften the effectiveness of regional cloning regulations. ${ }^{51}$

Finally, let us briefly consider the influence of global economics in this context. Economic considerations, while not as dominant as in the area of patent policies, also play a role in the policies of numerous countries. In fact, a number of countries have developed policy based in part on the belief that the regulatory environment that surrounds stem cell research will have a significant impact on the development of the biotechnology sector. For example, it is suggested that Singapore is "poised to become a beehive for biomedical research. This reflects a deliberate economic policy to diversify the electronics dominated manufacturing sector. The Singapore government has earmarked three billion dollars (US 1.6 billion) to promote research and development in the life sciences." 52 To this end, the Singapore Bioethics Advisory Committee has recommended that a wide variety of embryonic stem cell

4) See e.g. Pattinson, supra note 36.

50 For example, Ireland's restrictions on research involving human embryos is obviously informed by the country's strong Catholic tradition. Likewise, in Israel, the government's support of embryonic stem cell research and therapeutic cloning flows, in part, from the Jewish perspective on the status of the early fetus. See Michael Gross \& Vardit Ravitsky, "Israel: Bioethics in a Jewish-Democratic State" (2003) 12 Camb. Q. Health. Ethics 247 at 250:

in contrast to the Catholic view, which treats the embryo as a person from the moment of conception, Jewish and Muslim traditions see an embryo that progressively acquires human status during embryonic development. According to the Orthodox Jewish view, genetic materials outside the uterus have no legal status because they are not considered part of a human being until implantations. Therefore, the status of the preimplantation embryo outside the womb is comparable to that of gametes - namely, it should not be wasted but may be manipulated for therapeutic purposes.

51 See Daar, supra note 36, there are, of course, many reasons why a given jurisdiction may wish to pass laws that govern what happens within its borders, even though a national law may do little to stop the eventual proliferation of a controversial technology. Nevertheless, the law would still stand as a symbolic statement of the formal position of the nation on the appropriateness of the technology.

52 Taiwo Oriola, "Ethical and Legal Issues in Singapore Biomedical Research" (2002) 11 Pac. Rim. L. and Pol'y 497 at 497. 
research be permitted, including research cloning. ${ }^{53}$ At the same time, commentators have noted that the U.S.'s harsh stand on embryonic stem cell research and research cloning may hurt their research infrastructure. ${ }^{54}$ Daar believes that a "byproduct of a [U.S.] ban on scientific research would be a 'brain drain,' as talented and well-funded scientists leave the United States to establish research centers in nations with hospitable working environments." 55 In Canada, some have suggested that our more permissive regulatory environment may lead to a "brain gain."

\section{CONCLUSION}

This article has outlined a few of the regulatory challenges created by globalization in the area of biotechnology. ${ }^{57}$ Given the momentum of the international biotechnology industry, globalization will undoubtedly make it more difficult to drastically alter existing patent policies, even in the face of mounting evidence that such change may be required. Likewise, globalization forces will make it more difficult to regulate the development and use of controversial innovations, such as human cloning technology. Because of diverse moral and socio-political positions, building the international consensus which would be necessary to effectively regulate the area, seems all but impossible.

In general, I paint a pessimistic picture, at least for those hoping for substantial policy reform. In addition, I do not provide my own solutions to these complex problems. However, simply appreciating the magnitude of the challenges created by globalization in the area of biotechnology is an essential step in the policy-making process.

See M.H. Regnier \& B.M. Knoppers, "International Initiatives" (2002) 11 Health Law Review 13; see also "Cellular Therapy Company Established R\&D Centers in Singapore and U.S.," Editorial (1 1 \& 18 March 2002) Stem Cell Week, online: NewsRx <www.newsrx.net>.

In the U.S., federal funding will only be provided for stem cell research involving the limited number of stem cell lines that existed prior to the development of President Bush's policy. The federal government is also considering a ban on all forms of research involving human cloning, including "research cloning" ("Conundrums," supra note 48). As noted by Daar, supra note 36 at 570 . Daar suggests that U.S. policy has already caused researchers to relocate in Britain, where "therapeutic" or research cloning is potentially permissible (ibid.).

Carolyn Abraham, "Bush's Stem Cell Policy Could Mean Brain Gain for Canada (11 August 2002) Globe and Mail Al at Al: "Canada stands to become an attractive destination for American researchers looking for scientific freedom after U.S. President George W. Bush imposed tough restrictions on one of the hottest fields in medicine." In an area as morally and socially significant as stem cell research and human cloning, concerns about forum shopping, brain drain and domestic economics should, arguably, be at the bottom of a government's list of considerations. of course, many other biotechnology innovations that are relevant to this discussion, including genetically modified foods, xenotransplantation, and germ line therapy. 